\title{
Drought and saltwater incursion synergistically reduce dissolved organic carbon export from coastal freshwater wetlands
}

\author{
Marcelo Ardón • Ashley M. Helton • \\ Emily S. Bernhardt
}

Received: 25 June 2015/ Accepted: 19 January 2016

(C) Springer International Publishing Switzerland 2016

\begin{abstract}
The hydrologic transport of dissolved organic carbon (DOC) represents both a primary energetic loss from and a critical energetic link between ecosystems. Coastal freshwater wetlands serve as a primary source of DOC to estuaries; historically the magnitude and timing of DOC transfers has been driven by water movement. Extensive agricultural development throughout the coastal plain of the southeastern US has hydrologically connected much of the landscape via canals to facilitate drainage. The resulting large-scale loss of topographic relief and reduced mean elevation is interacting with increasingly frequent and severe droughts to facilitate the landward movement of seawater through the highly
\end{abstract}

Responsible Editor: Mark Brush.

M. Ardón $(\square)$

Department of Biology, East Carolina University, Greenville, NC 27858, USA

e-mail: ardonsayaom@ecu.edu;

marcelo.ardon@gmail.com

\section{A. M. Helton}

Department of Natural Resources and the Environment \& Center for Environmental Sciences and Engineering,

University of Connecticut, Storrs, CT 06269, USA

E. S. Bernhardt

Department of Biology, Duke University, Durham,

NC 27708, USA connected artificial drainage networks. The resulting changes in hydrologic regime and salinity are each expected to reduce DOC export from coastal freshwater wetlands, yet their individual and combined impacts are not well understood. Here we show that repeated saltwater incursion during late summer droughts substantially decreased DOC concentrations in surface water (from $\sim 40$ to $\sim 18 \mathrm{mg} / \mathrm{L}$ ) from a mature and a restored forested wetland in the coastal plain of North Carolina, USA. These declines in DOC concentration reduced annual export of DOC to the estuary by $70 \%$ and dampened storm fluxes by $76 \%$. We used a long-term experiment with intact soil columns to measure the independent and combined effects of drought, salinity, and sulfate loading as potential drivers of the large changes in DOC concentration. We found that soil drying and salinization each reduced DOC similarly (20\% reduction by drought alone, $29 \%$ by salinization) and their combined effect was additive (49\% reduction in salinization + drought treatments). Our results demonstrate that, well in advance of significant sealevel rise, drought and relatively low levels of saltwater incursion $(<6 \mathrm{ppt})$ are already significantly altering the timing and magnitude of dissolved organic carbon flux between coastal forested wetlands and downstream estuaries.

Keywords Climate change - Saltwater intrusion . DOC export - Drought · Forested wetlands - Storms . Sea-level rise 


\section{Introduction}

The transport of dissolved organic carbon (DOC) from freshwater to marine ecosystems is an important link between terrestrial and ocean carbon pools (Hedges et al. 1997). Current estimates are that freshwater ecosystems transport, mineralize, and bury $\sim 2.7 \mathrm{Pg} \mathrm{C}_{\text {year }}{ }^{-1}$, which is similar in magnitude to the terrestrial carbon sink (Battin et al. 2009). As DOC moves through aquatic ecosystems it plays important roles fueling food webs, regulating acidity, transporting pollutants, limiting light availability, and linking biogeochemical cycles (Battin et al. 2008). Aquatic DOC also plays a critical role in linking continental and marine carbon cycles, by exporting terrestrially derived organic matter to the coastal ocean. Although all inland systems contribute to coastal DOC loading, the quantity and composition of DOC exported to estuaries is largely driven by fresh, brackish, and saline wetlands of the coastal margin (Mulholland 2003). Given that coastal wetlands are the main source of organic carbon delivered to estuaries in the Atlantic and Gulf coasts of the United States (Shih et al. 2010), it is important to understand the factors controlling DOC export.

Extensive research has documented the important role of coastal marshes as sources, sinks, and transformers of organic matter exported to estuaries (Teal 1962; Nixon 1980; Tzortziou et al. 2008). However, not much work has been conducted on organic carbon export from forested coastal wetlands (Bauer et al. 2013). While tidal exchange has been shown to be an important driver of DOC export in marshes (Tzortziou et al. 2008, 2011), the timing and magnitude of rainfall is also likely to be important in forested coastal wetlands where tidal exchange is smaller (AlvarezCobelas et al. 2012; Chow et al. 2013). Prior studies in forested wetlands have shown that large flood events can export tremendous quantities of DOC, while droughts typically reduce DOC export (Clark et al. 2005; Eimers et al. 2008; Raymond and Saiers 2010), although other studies suggest that drought could increase DOC export from some wetlands (Fenner and Freeman 2011). Changes in the sequence of droughts and storms could also alter DOC export, for example storms following drought periods tend to be particularly DOC rich, as they flush organic matter that has accumulated over long time periods in hydrologically disconnected areas (Raymond and Saiers 2010;
Mehring et al. 2013). With predicted increases in the frequency of droughts and increased intensity of storms for much of the southeastern United States (Carter et al. 2014), it is important to understand how these changes to hydrologic conditions are going to alter DOC export from coastal wetlands.

Further complicating our ability to predict the consequences of hydrologic changes for coastal wetland DOC export, droughts in southeastern US coastal plain can also be associated with increases in salinity, as reductions in freshwater runoff allow landward movement of marine salts (Day et al. 2007; Anderson and Lockaby 2012; Ardón et al. 2013). Rising sea levels exacerbate this increased potential for the movement of salts from sea to land, making increased salinity the leading edge of climate change in this region. One of the challenges in forecasting the consequences of increased salinity on DOC export is that it can both increase and decrease DOC concentrations through various mechanisms (Herbert et al. 2015). High salinity can decrease the amount of autochthonous DOC produced in freshwater wetlands by decreasing terrestrial and aquatic plant productivity (Brinson et al. 1995; Krauss et al. 2009; Neubauer 2013). High concentrations of cations (especially $\mathrm{Ca}^{2+}$ and $\mathrm{Mg}^{2+}$ ) can also decrease DOC solubility by stimulating aggregation and flocculation (Sholkovitz 1976; Mulholland 1981). Salinity can also decrease the vulnerability of dissolved organic matter to photobleaching (Minor et al. 2006). In contrast, salinity can increase rates of organic matter mineralization as a result of enhanced rates of sulfate reduction due to the high inputs of marine sulfate, which could increase DOC production (Weston et al. 2011; Chambers et al. 2014). Changes in salinity can also increase water $\mathrm{pH}$, which increases the solubility of soil organic matter (Thurman 1985). Most of the studies on the effects of salinity on DOC concentrations in coastal wetlands have been conducted at the soil core or plot scale (Chambers et al. 2011, Weston et al. 2011, Neubauer 2013), thus the net effect of increased salinity events on DOC production and export at the ecosystem scale from coastal forested wetlands remains poorly understood (Henman and Poulter 2008).

We previously reported that drought-induced seasonal saltwater incursion led to dramatic increases of ammonium $\left(\mathrm{NH}_{4}{ }^{+}\right)$export from coastal plain wetlands (Ardón et al. 2013). Here, we examined the 
consequences of drought-induced saltwater incursion on DOC export from a mature forested wetland and a restored wetland for 5 years following its hydrologic reconnection to coastal waters. We complemented these field observations with a microcosm experiment in which we independently and synergistically manipulated water, salinity, and sulfate availability in intact soil columns. We hypothesized that: (1) drought would decrease DOC concentration and export; (2) increased salinity would decrease DOC concentrations in field and the laboratory; and (3) salinity-induced decreases in DOC concentrations would decrease storm, seasonal, and annual DOC export.

\section{Methods}

Site description

This study focuses on wetlands draining to the Albemarle Sound from the coastal plains of North Carolina, USA. The Albemarle Sound is sheltered from lunar tidal influence of the Atlantic Ocean by a chain of barrier islands (Outer Banks), resulting in wind driven tides for its fringing wetlands (Corbett et al. 2007). Salinity in the Albemarle Sound tends to be less than 5 parts per thousand (ppt; Corbett et al. 2007), but during drought years it can go up to $12 \mathrm{ppt}$ as a result of reduced freshwater inflow and enhanced evaporation (Division of Marine Fisheries, North Carolina Department of Environment and Natural Resources, personal communication).

The Timberlake Observatory for Wetland Restoration (TOWeR), located in Albemarle Peninsula in Tyrell County, NC ( $35^{\circ} 54^{\prime} 22^{\prime \prime} \mathrm{N} 76^{\circ} 09^{\prime} 25^{\prime \prime} \mathrm{W}$ ), is owned by the Great Dismal Swamp Mitigation Bank, LLC (Fig. 1). The total area of TOWeR is 1704.2 ha comprised of: 420 ha of mature forested wetland, 787 ha of forested wetland (drained by the Inflow), 57.2 ha of drained shrub-scrub, and 440 ha of former agricultural fields undergoing stream and wetland restoration. This study focuses on the 440 ha former agricultural field (Fig. 1). The Inflow drains forested wetland that was never in agricultural production (Fig. 1). The single outflow from the site drains into the Little Alligator River (3 km downstream), which drains to the Alligator River and the Albemarle Sound (5 km downstream). Active pumping necessary for agricultural production hydrologically disconnected

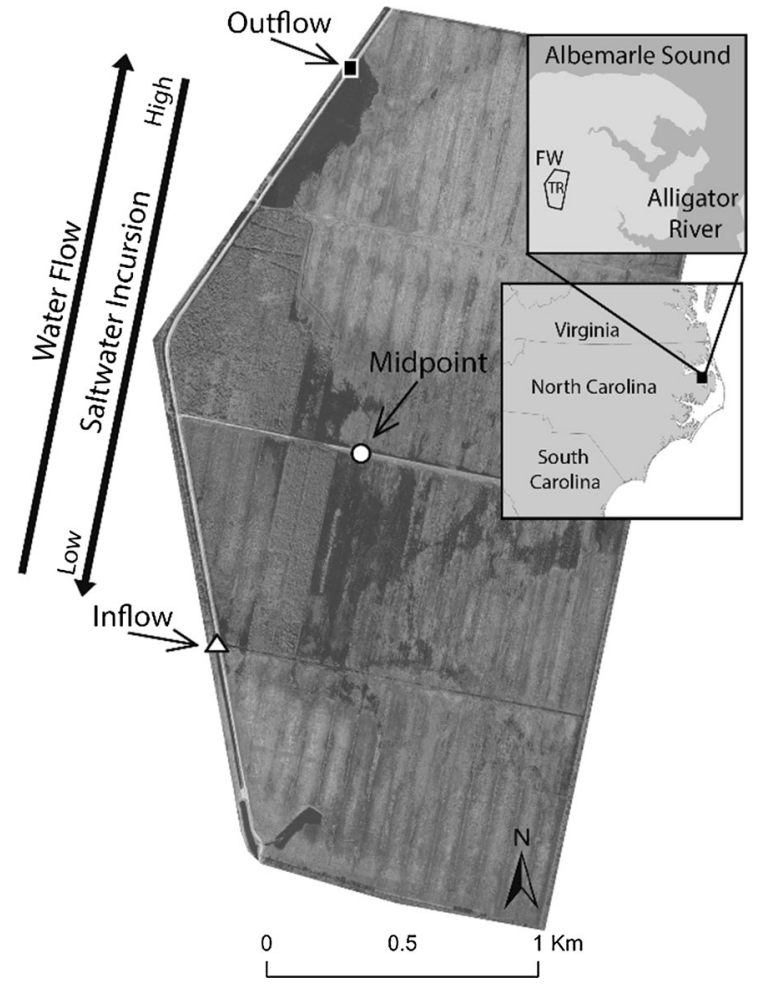

Fig. 1 Map of the former agricultural field undergoing restoration within Timberlake observatory for wetland restoration (TOWeR) with locations of surface water sampling sites. Bold arrows indicate direction of dominant water flow (north) and salinity gradient (south). Insert shows location within North Carolina (TR TOWeR site, $F W$ mature forested wetland)

the site from the Albemarle Sound until restoration started in 2007. Restoration also included planting of 750,000 live saplings from eight different species of native trees (Ardón et al. 2010). Soils at the restored site are composed mostly of Ponzer muck (loamy, mixed, dysic, themic Terric Haplosaprists) and Hyde loam (fine-silty, mized active, thermic Typic Umbraquults, USDA SSURGO Database 2005). The elevation at the site ranges from -1 to $2 \mathrm{~m}$ above sea level (lidar survey by National Center for Airborne Laser Mapping 2008, Houston, Texas, USA). The site has been described in detail in Ardón et al. (2010). To illustrate changes since restoration we included photos of the site in 2007 and 2012 in Appendix Fig. 7.

Since hydrologic reconnection the site has experienced seasonal saltwater incursion events during late summer and into winter, associated with decreased rainfall. Salinity in surface water at the site is less than $0.5 \mathrm{ppt}$, but during saltwater incursion events it 
increased to $>5$ ppt. Monitoring of groundwater (using piezometers at 15, 30, 60, and $100 \mathrm{~cm}$ ) has confirmed that salinity incursion occurred through surface water, and not through groundwater exchange (Ardón et al. 2013).

Water flow measurements and export calculations

Rainfall was measured at two sites using tipping bucket rain gauges ( 0.01 inch rain tip gauge, Teledyne ISCO, Lincoln NE, USA). To determine water export from the site, water depth and velocity were recorded every 15 min from 25 February 2007 to 25 February 2012 using acoustic Doppler area velocity meters (2150 Area Velocity Meter, Teledyne ISCO, Lincoln, Nebraska, USA) from the main Inflow and Outflow (Fig. 1). Because both Inflow and Outflow are through culverts, we used the known area of the culvert, water depth, and velocity to estimate discharge. Due to the slow water movement and influence of wind tides which reversed the flow $<1 \%$ of the time water velocity measurements were difficult and at times unreliable. Based on our extensive dataset, we identified outliers (more than one order of magnitude greater than the highest velocity recorded using handheld flow meter) and interpolated between measurements using weighted averages (Ardón et al. 2010). We discarded and interpolated data for $12 \%$ of the data from the Outflow, and this was primarily during low flows, when export was lowest. Less than $1 \%$ of the total measurements of velocity at the Outflow were negative (meaning flowing into the site), thus flow was primarily leaving the site. Here we report export data from the Outflow because our main interest in this paper was to examine how salinity and drought changed export of DOC to the downstream estuary.

To estimate solute export we multiplied concentrations derived from weekly sampling by estimates of daily discharge. We calculated daily discharge $\left(\mathrm{Q}_{\mathrm{d}}\right.$; L/d) from our 15 min discharge measurements (described above) by assuming each instantaneous measurement represented the next $15 \mathrm{~min}$ and summed for each day. For dates that corresponded to weekly sampling dates, we multiplied measured concentration $\left(\mathrm{C}_{\mathrm{d}} ; \mathrm{kg} / \mathrm{L}\right)$ by daily discharge. For dates between weekly sampling dates, we estimated $\mathrm{C}_{\mathrm{d}}$ as the average concentration from the prior and subsequent weekly samples according to Likens and Bormann (1995). To estimate yield (Y; $\mathrm{kg} \mathrm{ha}^{-1}$ year $^{-1}$ ) we summed daily export for the year and divided by the area of the former agricultural field (A; $440 \mathrm{ha}$ ), using the equation:

$Y=\frac{\sum\left(Q_{d} C_{d}\right)}{A}$

\section{Surface water sampling}

To determine DOC and solute concentrations in surface water, weekly water samples were collected from February 2007 to February 2012 from three sites within the restored area: Inflow, Midpoint, and Outflow (Fig. 1). These sites spanned the salinity gradient and cover the main inflow and outflow from the site. Samples were filtered immediately (GF/F Whatman filters, $0.7 \mu \mathrm{m}$ ), refrigerated and maintained at $4{ }^{\circ} \mathrm{C}$ until analyzed. Dissolved organic carbon (DOC, measured as non-purgeable organic carbon) and total dissolved nitrogen (TDN) were measured on a Shimadzu TOC-V total carbon analyzer with a TNM-1 nitrogen module (Shimadzu Scientific Instruments, Columbia, Maryland, USA). Soluble reactive phosphorus (SRP) and $\mathrm{NH}_{4}{ }^{+}-\mathrm{N}$ were measured using the molybdenum blue and phenate methods respectively on a Lachat QuickChem automated system. $\mathrm{NO}_{3}{ }^{-}-\mathrm{N}$, $\mathrm{Cl}^{-}$and $\mathrm{SO}_{4}{ }^{2-}$ were measured on a Dionex ICS-2000 ion chromatograph (Dionex Corporation, Sunnyvale, California, USA). We calculated dissolved organic nitrogen (DON) concentrations as $\mathrm{DON}=\mathrm{TDN}-$ $\left(\mathrm{NO}_{3}{ }^{-}-\mathrm{N}+\mathrm{NH}_{4}{ }^{+}-\mathrm{N}\right)$. We calculated the carbon to nitrogen ratio $(\mathrm{C}: \mathrm{N})$ of dissolved organic matter (DOM) as the molar ratio of DOC to DON. Water $\mathrm{pH}$, dissolved oxygen, conductivity, and temperature were measured every time we collected water samples using a handheld multiprobe device which was calibrated before measurements were collected (YSI Multiprobe Model 560, Yellow Springs, Ohio, USA).

Because in many systems the majority of DOC is exported during storms, we explored the extent to which salinity affected storm DOC fluxes. In addition to weekly samples we did high frequency sampling after rain storm events to estimate storm fluxes. We used automated samplers (ISCO 6712, Teledyne ISCO, Ohio, USA) to collect samples every $2-10 \mathrm{~h}$ to characterize the rising and falling limbs after rainfall events. Samples were collected from the automated samplers within a week of collection, 
filtered in the laboratory, and refrigerated until analyses. Samples were analyzed as described above for weekly samples. We used the concentrations from approximately 24 samples per storm together with flow measurements to estimate storm fluxes of DOC for a total of 16 events.

\section{POC formation assays}

To examine the potential for salt-induced flocculation, we measured the amount of particulate organic $\mathrm{C}$ (POC) formation in water samples collected during the summer from the Outflow under different salinities. We made artificial saltwater following (Kester et al. 1967). We added different amounts of artificial saltwater to 4 replicated $500 \mathrm{ml}$ samples to obtain a range in conductivity similar to that observed in the field $(0-12 \mathrm{mS} / \mathrm{cm}$, salinity $=0-6 \mathrm{ppt})$. POC formation was determined gravimetrically. We filtered the samples (on pre-combusted $0.7 \mu \mathrm{m} \mathrm{GF} / \mathrm{F}$ ) before adding saltwater and $24 \mathrm{~h}$ after adding saltwater. Following filtration, filters were dried $\left(70{ }^{\circ} \mathrm{C}\right.$ for $\left.48 \mathrm{~h}\right)$ and weighed. We determined organic matter by combusting the samples $\left(500{ }^{\circ} \mathrm{C}\right.$ for $4 \mathrm{~h}$ ), and we assumed half of particulate organic matter was $\mathrm{C}$ (Mulholland 1981).

\section{Microcosm Experiment}

To disentangle the effects of drought, salinity and sulfate on DOC concentration, we conducted a microcosm experiment using intact soil cores from the TOWeR site. On 26 July 2010 we collected 50 intact soils cores (30 cm tall, $2.5 \mathrm{~cm}$ diameter) from an area of the site that has not previously experienced saltwater incursion. The microcosms consisted of the main soil core connected to a reservoir $(30 \mathrm{~cm}$ tall, $5 \mathrm{~cm}$ diameter, PVC), which allowed us to manipulate both the water elevation within the soil core and water chemistry [our design was modified from Clark et al. (2006) and is explained in detail in Ardón et al. (2013)]. To sample soil solution, each core was instrumented with three microlysimeters $(5 \mathrm{~cm}$, glass fiber, Rizhon MOM, Rhizhosphere Research Products, The Netherlands) at three depths $(5,15$, and $25 \mathrm{~cm}$ from the soil surface). Ten of the 50 initial cores were used to determine initial soil nutrient and physical characteristics. The other 40 cores were assigned to one of two hydrologic treatments (drought and flooded) and one of four water chemistry treatments $(\mathrm{n}=5$ replicates per treatment). Water chemistry treatments were designed to discern the individual effects of increased salinity and increased sulfate from seasalts. To make the water chemistry treatments we modified a recipe for artificial saltwater from Kester et al. (1967) to make the following treatments: control (deionized water), artificial saltwater (Salinity $=5$ ppt, $\mathrm{Cl}^{-}>1000 \mathrm{mg} \mathrm{L}^{-1}$, ASW), artificial saltwater without sulfate $\left(\mathrm{S}=5 \mathrm{ppt}, \mathrm{Cl}^{-}>1000 \mathrm{mg} \mathrm{L}^{-1}\right.$, $\mathrm{ASW}-\mathrm{SO}_{4}$ ), and deionized water with the same sulfate concentrations as the artificial saltwater treatments $\left(\mathrm{SO}_{4}{ }^{2-}>100 \mathrm{mg} \mathrm{L}^{-1}, \mathrm{SO}_{4}{ }^{2-}\right)$. The cores were maintained in a dark walk-in environmental chamber at $30^{\circ}$ $\mathrm{C}$ and $20 \%$ humidity for the 12 weeks of the experiment. The cores were set up on 9 August 2010, flooded with deionized water and allowed to equilibrate for 2 weeks before applying the treatments. Water level was maintained above the soil surface in the flooded treatments and above the $-25 \mathrm{~cm}$ sampling microlysimeters in the drought treatments for the duration of the experiment.

We sampled soil solution on 24 August 2010 before initiating treatments on 25 August 2010. From that point forward each core received sufficient treatment water to maintain desired water levels. We collected soil solution samples weekly for the first 2 weeks and biweekly for the last 8 weeks. Soil solution was collected by connecting a $5 \mathrm{ml}$ syringe to each of the microlysimeters, adding a vacuum and allowing the syringe to fill overnight. Samples were collected in clean HDPE scintillation vials and either analyzed immediately or frozen until analyses (within 3 weeks) as described above.

\section{Statistical analyses}

We compared DOC and DON concentrations among sites using analyses of variance (ANOVA) and post hoc Tukey tests. To examine the effects of saltwater incursion on DOC concentrations in the field data, we compared DOC between samples that had salinities below the brackish limit ( $\mathrm{S}=0.5 \mathrm{ppt}$ or $280 \mathrm{mg} / \mathrm{L}$ $\mathrm{Cl}^{-}$) to samples that had salinities above that limit using ANOVA. We also used ANOVAs to compare DOC fluxes between storms occurring in periods of low salinity $\left(\mathrm{Cl}^{-}<280 \mathrm{mg} / \mathrm{L}\right)$ and periods of high salinity $\left(\mathrm{Cl}^{-}>280 \mathrm{mg} / \mathrm{L}\right)$. For the Inflow, Midpoint, and Outflow, we performed multiple linear regression 
Fig. 2 Dissolved organic carbon concentrations (mg/L, black circles) and conductivity $(\mathrm{mS} / \mathrm{cm}$, white circles) in three sampling sites in TOWeR (a, c, e). Relationship between DOC and chloride concentrations for the same sites $(\mathbf{b}, \mathbf{d}, \mathbf{f})$. Rainfall received across the site (g), arrows indicate major storms, in 2010 tropical storm Nicole and in 2011 Hurricane Irene
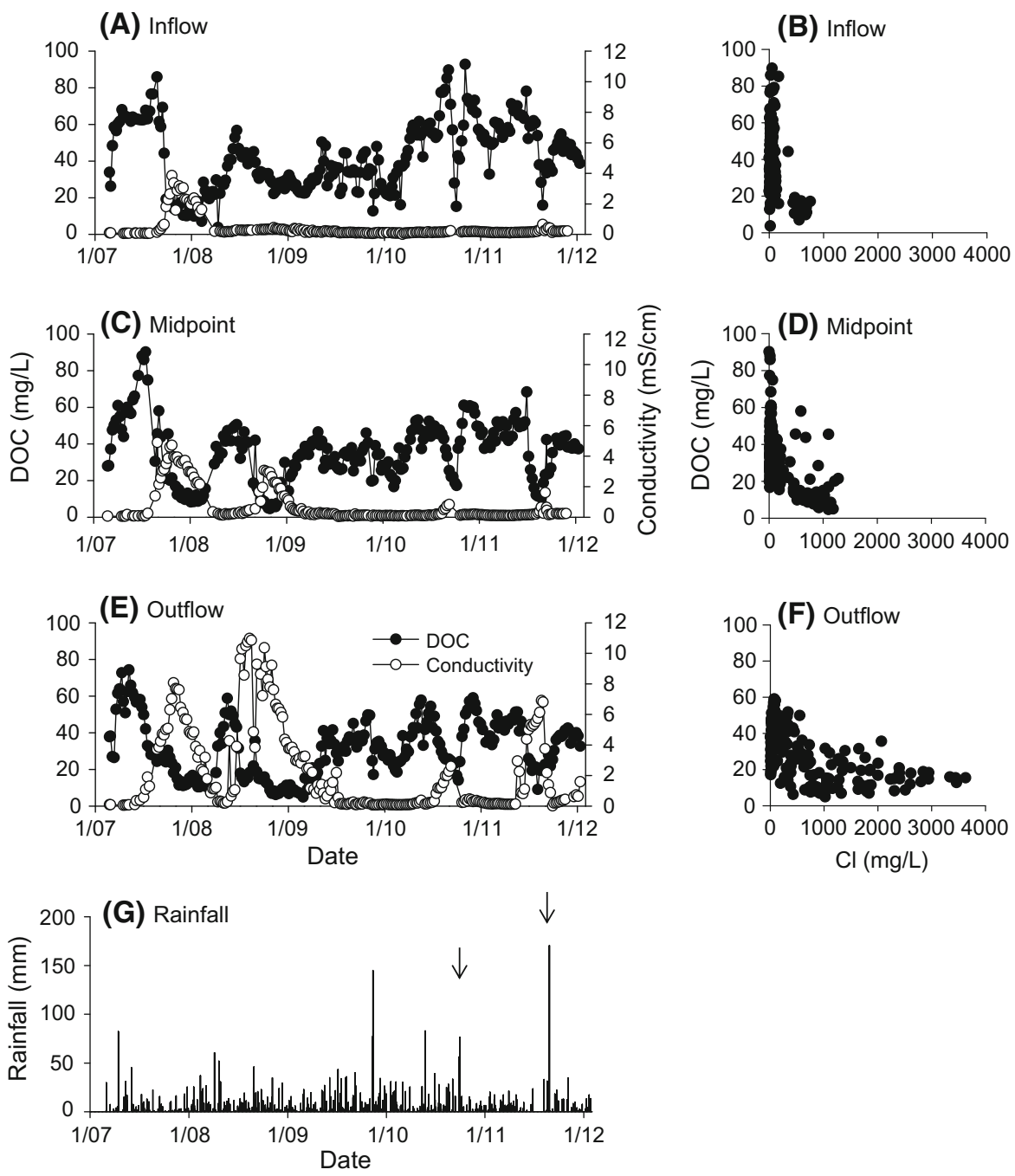

model selection with DOC and C:N ratio (2007-2012, $\mathrm{n}=255$ per site) using regsubsets() in the LEAPS package in R. Dependent variables for the DOC regression analysis included dissolved solute concentrations $\left(\mathrm{NO}_{3}{ }^{-}, \mathrm{SRP}, \mathrm{Cl}^{-}\right), \mathrm{pH}$, water temperature, and discharge. We did not include conductivity, $\mathrm{SO}_{4}{ }^{2-}$, or $\mathrm{NH}_{4}{ }^{+}$because they were strongly correlated with $\mathrm{Cl}^{-}\left(\mathrm{r}^{2}>0.60\right.$ at one or more of the sites). Water level was also not included because it was strongly correlated with temperature $\left(\mathrm{r}^{2}>0.60\right.$ at one or more of the sites). Dependent variables for $\mathrm{C}: \mathrm{N}$ ratio included dissolved solute concentrations $\left(\mathrm{NO}_{3}{ }^{-}\right.$, $\mathrm{SRP}, \mathrm{Cl}^{-}$), $\mathrm{pH}$, water temperature, and discharge. We also used ANOVA on the microcosm DOC data using hydrology, salinity, and sulfate as factors, followed by a post hoc Tukey test of means. Statistical analyses were performed in R 2.13.0 (The R Foundation for Statistical Computing 2011) and JMP (SAS, Cary, North Carolina, USA).

\section{Results}

Surface water

During four out of the 5 years, TOWeR experienced drought conditions which led to increased salinity and reductions in DOC (Fig. 2). The magnitude of change in both conductivity and DOC concentrations varies across the years, with severe droughts of 2008 and 2009 
Table 1 Mean (and standard deviation) for DOC and DON concentrations for three sites at TOWeR

\begin{tabular}{llllll}
\hline & DOC & DON & $\mathrm{Cl}^{-}$ & $\mathrm{SO}_{4}{ }^{2-}$ & $\mathrm{C}: \mathrm{N}$ \\
\hline Inflow & $42.87^{\mathrm{a}}(18.4)$ & $1.39^{\mathrm{a}}(0.52)$ & $102.23^{\mathrm{a}}(168.9)$ & $11.90^{\mathrm{a}}(13.1)$ & $37.78^{\mathrm{a}}(15.6)$ \\
Midpoint & $35.84^{\mathrm{b}}(16.1)$ & $1.29^{\mathrm{a}}(0.57)$ & $216.52^{\mathrm{b}}(327.6)$ & $13.28^{\mathrm{a}}(17.8)$ & $32.74^{\mathrm{b}}(10.1)$ \\
Outflow & $31.58^{\mathrm{c}}(15.2)$ & $1.19^{\mathrm{b}}(0.58)$ & $622.38^{\mathrm{c}}(833.4)$ & $62.26^{\mathrm{b}}(98.1)$ & $30.75^{\mathrm{b}}(19.3)$ \\
\hline
\end{tabular}

DOC, DON $\mathrm{Cl}^{-}$, and $\mathrm{SO}_{4}{ }^{2-}$ concentrations $(\mathrm{mg} / \mathrm{L})$ are based on 5 years of weekly sampling. C:N is the molar ratio of DOC to DON. Letters denote significant differences among sites based on ANOVA and post hoc Tukey test $(\mathrm{p}<0.05)$

Table 2 Multiple linear regression coefficient estimates for best model (Appendix Table 5 for all model statistics) for DOC concentrations and $\mathrm{C}: \mathrm{N}$ ratio at the Inflow, Midpoint, and Outflow

All significant at $\mathrm{p}<0.1$ except for those marked with $*$, in which $\mathrm{p}<0.05$

\begin{tabular}{|c|c|c|c|c|c|c|}
\hline \multirow[t]{2}{*}{ Model } & \multicolumn{2}{|l|}{ Inflow } & \multicolumn{2}{|l|}{ Midpoint } & \multicolumn{2}{|l|}{ Outflow } \\
\hline & DOC & $\mathrm{C}: \mathrm{N}$ & DOC & $\mathrm{C}: \mathrm{N}$ & DOC & $\mathrm{C}: \mathrm{N}$ \\
\hline $\mathrm{R}_{\mathrm{adj}}^{2}$ & 0.39 & 0.29 & 0.57 & 0.37 & 0.61 & 0.16 \\
\hline Intercept & $49.99 *$ & $1.58 *$ & $38.87 *$ & $32.45^{*}$ & $19.68 *$ & $1.25 *$ \\
\hline $\mathrm{Cl}^{-}$ & $-0.054^{*}$ & $-0.0057 *$ & $-0.029 *$ & $-0.01 *$ & $-0.010 *$ & $-0.0088 *$ \\
\hline SRP & 233.87 & & $714.51 *$ & $340.18^{*}$ & $667.4^{*}$ & \\
\hline $\mathrm{pH}$ & $-4.44 *$ & & & 0.55 & 1.28 & $0.0061^{*}$ \\
\hline $\mathrm{NO}_{3}^{-}$ & -4.12 & & $-36.84 *$ & & $-46.45^{*}$ & \\
\hline Temp & $0.76^{*}$ & & & -0.12 & $0.37 *$ & \\
\hline Discharge & & & $-0.0059 *$ & $-0.0003 *$ & $-0.0001 *$ & \\
\hline
\end{tabular}

(Palmer Drought index was -1.92 during those 2 years) leading to larger and longer shifts in water chemistry than the less extreme dry periods of 2010-2012 (Fig. 2). During the 2008-2009 drought conductivity increased from less than $1 \mathrm{mS} / \mathrm{cm}$ to $\sim 11 \mathrm{mS} / \mathrm{cm}$ in the Outflow (salinity from 0 to $6 \mathrm{ppt}$ ), with less pronounced increases upstream at the Midpoint site from June 2008 to July 2009 (Fig. 2). We observed lower magnitude increases in conductivity from June to September 2010 and June to August 2011 (Fig. 2), but in both of these years the period of saltwater incursion was ended abruptly with the significant rains brought by tropical storm Nicole in 2010 (September 28-30) and hurricane Irene in 2011 (August 27-30).

Average DOC concentrations were higher in the Inflow (average $42.8 \pm 18.4 \mathrm{mg} / \mathrm{L}$ ) which drains a mature forested wetland, than at the Midpoint (35.8 \pm $16.1 \mathrm{mg} / \mathrm{L})$, or the Outflow $(31.6 \pm 15.2 \mathrm{mg} / \mathrm{L}$, Table 1). In all three sites, average DOC concentrations were $55 \%$ higher during freshwater periods (mean DOC $=42.2 \pm 14.9 \mathrm{mg} / \mathrm{L}, \mathrm{Cl}^{-}<280 \mathrm{mg} / \mathrm{L}$ ), compared to high salinity periods $(\mathrm{DOC}=18.9 \pm$ $11.1 \mathrm{mg} / \mathrm{L}, \mathrm{Cl}^{-}>280 \mathrm{mg} / \mathrm{L}$ ). The periods of lowest DOC concentrations in all three sites were associated with freshwater flushing by large storms (tropical storm Nicole and Hurricane Irene are indicated by arrows in Fig. 2) or periods of increased salinity (Fig. 2). DOC concentrations declined with increasing $\mathrm{Cl}^{-}$, explaining $23-40 \%$ of the total variation in DOC concentrations at each site (Table 2; Appendix Table 5). Other significant explanatory variables included water temperature, $\mathrm{pH}, \mathrm{NO}_{3}{ }^{-}$, discharge and phosphorus (SRP), with the best models explaining 40-61\% of the variation in DOC in all three sites (Table 2). DON concentrations were correlated with DOC concentrations at each site $\left(\mathrm{r}^{2}=0.43,0.58,0.59\right.$ for the Inflow, Midpoint, and Outflow respectively, $p<0.001)$. The carbon to nitrogen ratio of DOM in the field decreased from the Inflow (average C:N 37.8) to the Outflow (average C:N 30.8, Table 1), and declined with increasing salinity (Fig. 3). Linear regression models for $\mathrm{C}: \mathrm{N}$ ratio explained less of the variation (16-38\%) than models of DOC concentrations (Table 2, Appendix Table 5). $\mathrm{Cl}^{-}$was included in best fit models and alone explained 29, 28, and $8 \%$ of the variation in $\mathrm{C}: \mathrm{N}$ in the Inflow, Midpoint, and Outflow respectively. (Table 2; Appendix Table 5). Other significant explanatory variables in best fit models included SRP, discharge, water temperature, and $\mathrm{pH}$ (Table 2; Appendix Table 5). 
Annual DOC export ranged from a low of $\sim 50 \mathrm{~kg}$ $\mathrm{C} \mathrm{ha}^{-1}$ year $^{-1}$ in the 2 nd and 5 th years of our study to a high of $\sim 200 \mathrm{~kg} \mathrm{C} \mathrm{ha}^{-1}$ year $^{-1}$ in years 1,3 , and 4 (Table 3). The extreme low export of years 2 and 5 were associated with the highest salinities during July through December (average chloride concentration $=2378.3$ and $739.5 \mathrm{Cl}^{-} \mathrm{mg} / \mathrm{L}$ for $2008-2009$ and 2011-2012 respectively). A comparison of these 2 years is instructive. With 3 -fold higher salinity during July through December in 2008-2009, there was nearly identical DOC export in both years, even though there was nearly double the water export in the earlier year (Table 3). Comparing the annual export of the year without saltwater incursion (2009-2010) to years with extreme drought and saltwater incursion (2008-2009 and 2011-2012), suggests that the combination of drought and saltwater incursion decreased annual DOC export by 70-73\%. We also estimated the impacts of saltwater incursion events in another

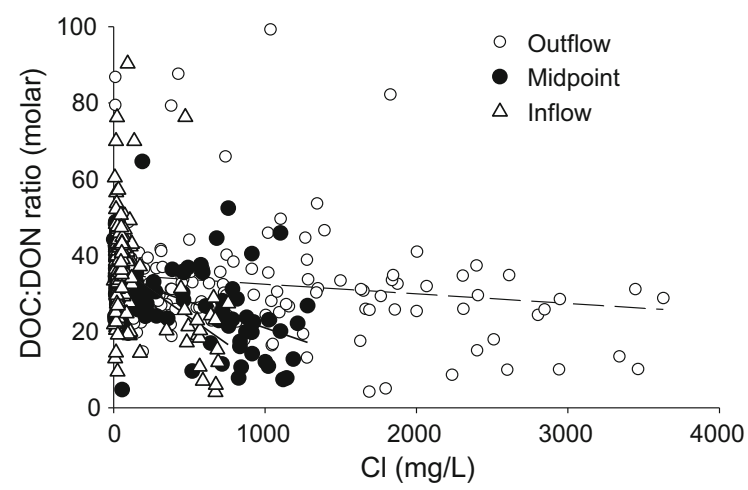

Fig. 3 Relationship between C:N ratio of dissolved organic matter and chloride concentrations for the three sampling sites in TOWeR way, by recalculating the seasonal export for 2008-2009 and 2011-2012 using the measured water flux, but replacing the weekly concentration data with Outflow DOC concentrations measured for those same weeks in 2009-2010, the only year in our record without saltwater incursion during July through December (Table 3). We estimate that seasonal DOC fluxes would have been 34.2 and $23.0 \mathrm{~kg} \mathrm{ha}^{-1}$ year $^{-1}$, instead of the measured 15.9 and $18.4 \mathrm{~kg} \mathrm{ha}^{-1}$ year $^{-1}$ for 2008-009 and 2011-2012 respectively, if there had been no saltwater incursion. This calculation suggests that increased salinity led to a $20-53 \%$ decline in seasonal DOC export.

We estimated fluxes for 16 storms over 4 years of sampling (2007-2010). We separated the 16 storms into storms that had low salinity $\left(\mathrm{Cl}^{-}\right.$concentrations less than $100 \mathrm{mg} / \mathrm{L}, \mathrm{n}=7$, mean $\mathrm{Cl}^{-}=38.8 \pm 14.8$ $\mathrm{mg} / \mathrm{L})$ and high salinity storms $\left(\mathrm{Cl}^{-}\right.$concentrations greater than $100 \mathrm{mg} / \mathrm{L}, \mathrm{n}=9$, mean $\mathrm{Cl}^{-}=1221.6 \pm$ $343.9 \mathrm{mg} / \mathrm{L}$ ). There was no significant difference in the amount of rain received during low (mean rainfall $=37.3 \pm 9.3 \mathrm{~mm}$ ) and high salinity storms (mean rainfall $30.2 \pm 8.2 \mathrm{~mm}, \mathrm{p}=0.57$ ). While total storm flow volume tended to be higher during low salinity periods (mean cumulative flow during low salinity periods $\left.=41,138 \pm 12,913 \mathrm{~m}^{3}\right)$ compared to high salinity periods (mean cumulative flow 21,656 \pm $6629 \mathrm{~m}^{3}$, Fig. 4), there was no significant difference $(\mathrm{p}=0.11)$. Increased total storm flow volume led to increased DOC export, but storms with high salinity exported $76 \%$ less DOC (mean DOC export $=310 \pm$ $141.2 \mathrm{~kg} / \mathrm{storm}$, Fig. 4a) compared to low salinity storms (mean DOC export $=1335 \pm 507.5 \mathrm{~kg} / \mathrm{storm}$ ) though the difference was marginally significant $(\mathrm{F}$ ratio $=4.13, \mathrm{p}=0.06)$. This decline in DOC export

Table 3 Water, DOC mass export, and average concentration (DOC and $\mathrm{Cl}^{-}$) for each of the 5 years (February 25 of 1 year to February 24 of the next year) and for the period when saltwater incursion commonly occurred (July through December)

\begin{tabular}{|c|c|c|c|c|c|c|c|c|}
\hline $\begin{array}{l}\text { Budget } \\
\text { year }\end{array}$ & $\begin{array}{l}\text { Annual } \\
\text { water flux } \\
\left(\times 10^{9} \mathrm{~L}\right)\end{array}$ & $\begin{array}{l}\text { July-Dec } \\
\text { water flux } \\
\left(\times 10^{9} \mathrm{~L}\right)\end{array}$ & $\begin{array}{l}\text { Annual DOC } \\
\text { yield } \\
\left(\mathrm{kg} \mathrm{ha}^{-1} \text { year }^{-1}\right)\end{array}$ & $\begin{array}{l}\text { July-Dec DOC } \\
\text { yield } \\
\left(\mathrm{kg} \mathrm{ha}^{-1} \text { year }^{-1}\right)\end{array}$ & $\begin{array}{l}\text { Annual } \\
\text { DOC } \\
(\mathrm{mg} / \mathrm{L})\end{array}$ & $\begin{array}{l}\text { July-Dec } \\
\text { DOC (mg/ } \\
\text { L) }\end{array}$ & $\begin{array}{l}\text { Annual } \\
\mathrm{Cl}^{-} \\
(\mathrm{mg} / \mathrm{L})\end{array}$ & $\begin{array}{l}\text { July-Dec } \\
\mathrm{Cl}^{-} \\
(\mathrm{mg} / \mathrm{L})\end{array}$ \\
\hline 2007-2008 & 2.01 & $0.68(34 \%)$ & 187.0 & $45.8(24 \%)$ & 41.8 & 26.1 & 280.4 & 665.6 \\
\hline 2008-2009 & 1.09 & $0.43(39 \%)$ & 54.9 & $15.9(29 \%)$ & 22.2 & 14.5 & 1136.9 & 2378.3 \\
\hline 2009-2010 & 3.00 & $2.26(75 \%)$ & 187.2 & $143.2(76 \%)$ & 27.4 & 34.8 & 35.5 & 72.9 \\
\hline 2010-2011 & 2.70 & $1.71(63 \%)$ & 203.9 & $125.2(63 \%)$ & 33.1 & 34.2 & 256.7 & 311.3 \\
\hline 2011-2012 & 0.59 & $0.29(49 \%)$ & 49.2 & $18.4(37 \%)$ & 36.6 & 27.5 & 151.7 & 739.5 \\
\hline
\end{tabular}

Percentages in parentheses for water flux and DOC export represent the percentage of the annual water and DOC flux that occurred between July and December 
(A)

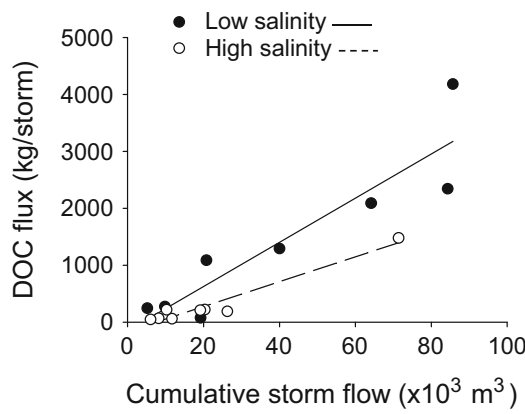

Fig. 4 a Relationship between storm export of DOC ( $\mathrm{kg}$ per storm) and flow $\left(\times 10^{3} \mathrm{~m}^{3}\right)$ from 16 storms from TOWeR site divided by low salinity conditions (dark circles, $\mathrm{Cl}^{-}$concentrations $<100 \mathrm{mg} / \mathrm{L}$, solid regression $\mathrm{r}^{2}=0.58, \mathrm{p}=0.02$ ) and high salinity conditions (white circles, $\mathrm{Cl}^{-}$

was in part because salinity was high during drought periods, which caused lower discharge after similar sized rain events (Fig. 4). DOC concentrations were on average $71 \%$ lower during high salinity periods compared to low salinity after similar rainfall events (low salinity mean volume weighted concentration $=32.7 \mathrm{mg} / \mathrm{L}$ compared to $11.4 \mathrm{mg} / \mathrm{L}$ during high salinity storms, $\mathrm{F}$ ratio $=11.49, \mathrm{p}<0.001)$. The hydrograph and DOC concentrations after a low and high salinity storm illustrate these differences in concentrations (Fig. 4B). Both storms received similar rainfall amounts ( $67.5 \mathrm{~mm}$ low salinity versus $78 \mathrm{~mm}$ ), and exhibited similar total cumulative flow $\left(64,154 \mathrm{~m}^{3}\right.$ low salinity versus $71,400 \mathrm{~m}^{3}$ high salinity storm), but concentrations during the high salinity storm were half that of the low salinity storm $(22.3 \mathrm{mg} / \mathrm{L}$ compared to $41.0 \mathrm{mg} / \mathrm{L}$, respectively, Fig. 4b).

POC formation assays

Adding artificial seawater to water samples from the TOWeR site collected during summer led to rapid flocculation, as measured by increased POC formation (Fig. 5). There was a linear increase in flocculation from 0.5 to $6 \mathrm{mS} / \mathrm{cm}$, with a smaller change in POC formation at the highest conductivity (Fig. 5). The maximum POC formation we observed was approximately $13 \%$ of the initial DOC concentration (Fig. 5). POC assays with water collected during
(B)

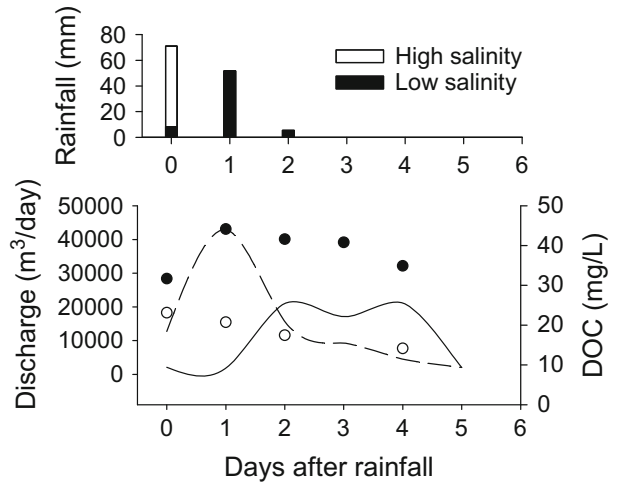

concentrations $>100 \mathrm{mg} / \mathrm{L}$, dashed regression, $\mathrm{r}^{2}=0.91$, $\mathrm{p}<0.05$ ). b Rainfall, flow (line), and DOC concentrations (circles) of a low salinity storm (black circles and solid line) and a high salinity storm (white circles and dashed line)

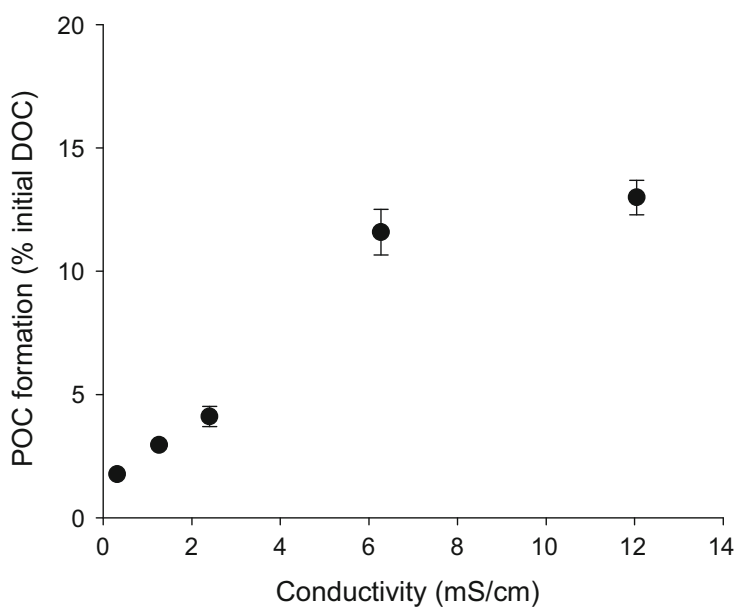

Fig. 5 Formation of particulate organic carbon (POC) as percentage of initial DOC under different salinities (as measured by conductivity)

other times of the year led to similar results (results not shown).

\section{Microcosm experiment}

In the microcosm experiment, $\mathrm{Cl}^{-}$concentrations increased in high salinity treatments to more than $2000 \mathrm{mg} / \mathrm{L}$, as compared to less than $20 \mathrm{mg} / \mathrm{L}$ in the freshwater treatments (Fig. 6a, b), and $\mathrm{SO}_{4}{ }^{2-}$ concentrations increased to more than $100 \mathrm{mg} / \mathrm{L}$ in high 
Fig. 6 Chloride $(\mathbf{a}, \mathbf{b})$, sulfate (c, d) and DOC (e, d) concentrations for drought (a, c, e) and flooded $(\mathbf{b}, \mathbf{d}, \mathbf{f})$ treatments in soil solution (15 cm depth) from the soil column experiment. Water chemistry treatments in each treatment are: control (DDI, black circles), artificial saltwater with sulfate (ASW), artificial saltwater without sulfate (ASW-SO ${ }_{4}{ }^{2-}$ ), and sulfate only $\left(\mathrm{SO}_{4}{ }^{2-}\right)$. Average DOC concentrations (g, regression line $\log$ DOC $=4.47-0.13 *(\log$ $\left.\left.\mathrm{Cl}^{-}\right), \mathrm{r}^{2}=0.67, \mathrm{p}<0.001\right)$ and DOC:DON ratio $(\mathrm{H}$, regression line $\mathrm{C}: \mathrm{N}=35.70-0.0065^{*} \mathrm{Cl}^{-}$, $\left.\mathrm{r}^{2}=0.28, \mathrm{p}<0.01\right)$ versus average chloride concentrations for the flooded salinity treatments (with and without sulfate)
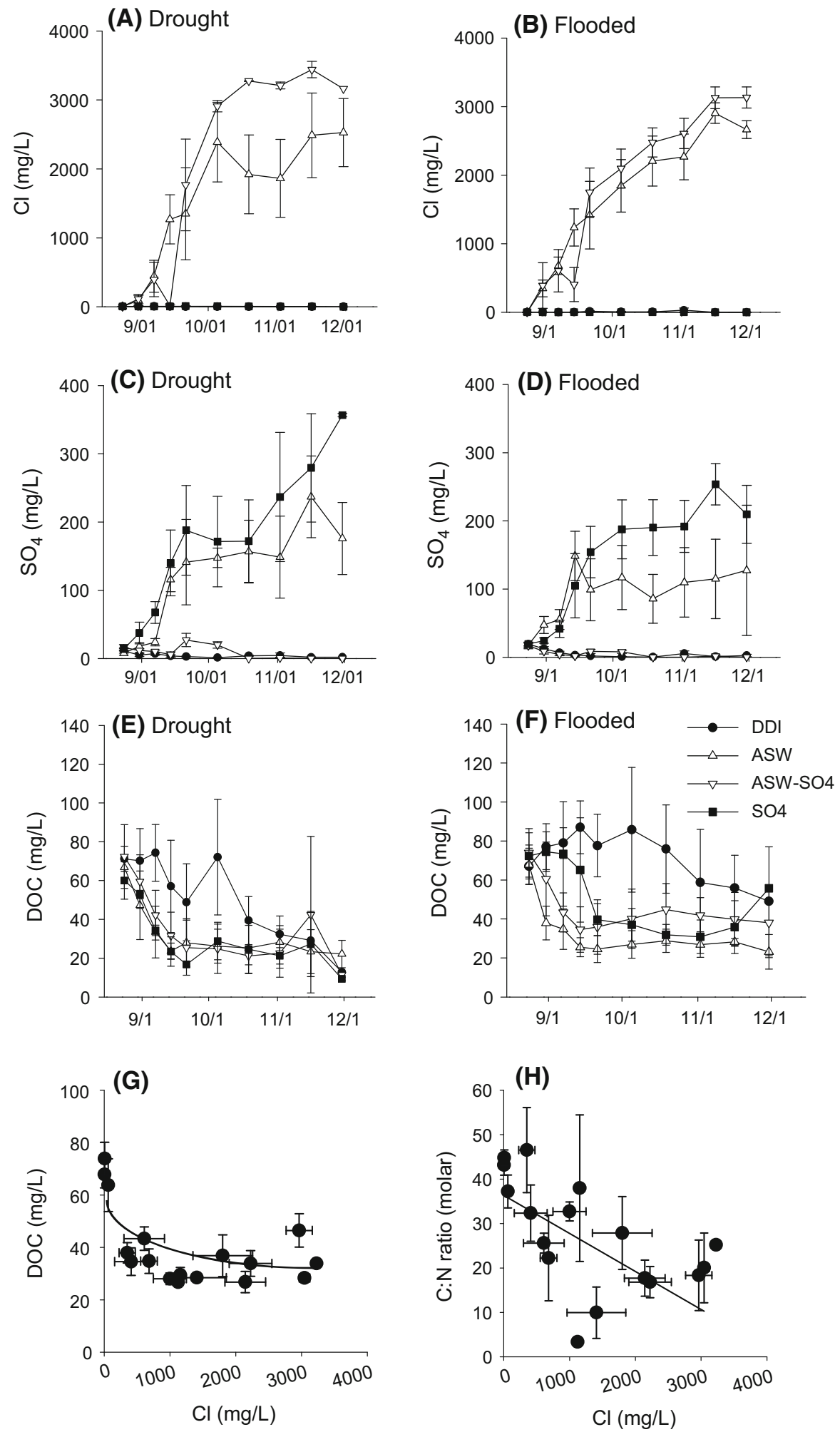

(H)

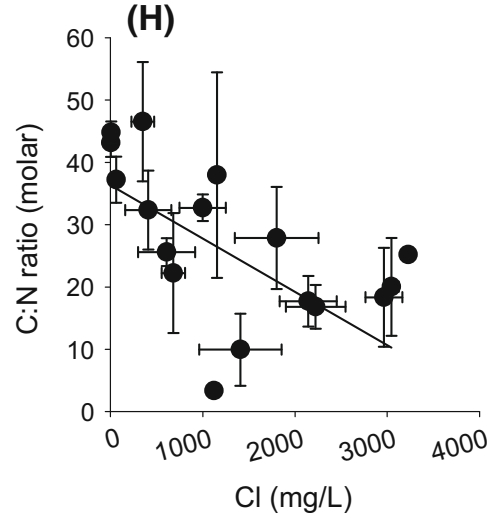


Table 4 Results of ANOVA on log transformed DOC concentrations (15 cm depth lysimeters) from the microcosm experiment

\begin{tabular}{llllr}
\hline Source & Degrees of freedom & Sum of squares & F ratio & Prob $>$ F \\
\hline Hydrology & 1 & 4.94 & 21.6 & $<.0001$ \\
Salt & 1 & 8.25 & 36.1 & 38.6 \\
$\mathrm{SO}_{4}$ & 1 & 8.82 & 6.5 & $\mathbf{< . 0 0 0 1}$ \\
$\mathrm{Hydrology} \times \mathrm{Salt}^{2-}$ & 1 & 1.48 & 0.04 & $\mathbf{0 . 0 1}$ \\
$\mathrm{Hydrology} \times \mathrm{SO}_{4}{ }^{2-}$ & 1 & 0.01 & 0.83 \\
Salt $\times \mathrm{SO}_{4}{ }^{2-}$ & 1 & 1.19 & 5.24 & $\mathbf{0 . 0 2}$ \\
Hydrology $\times \mathrm{Salt} \times \mathrm{SO}_{4}{ }^{2-}$ & 1 & 1.42 & 6.22 & $\mathbf{0 . 0 1}$ \\
\hline
\end{tabular}

Hydrology factor included two treatments (drought and flooded) while salt and sulfate were present or absent. Bold font indicates significant differences

$\mathrm{SO}_{4}{ }^{2-}$ treatments, compared to less than $30 \mathrm{mg} / \mathrm{L}$ in the low $\mathrm{SO}_{4}{ }^{2-}$ treatments (Fig. 6c, d). Drought, salinity, and $\mathrm{SO}_{4}{ }^{2-}$ treatments all led to significant decreases in DOC concentrations in soil solution (Fig. 6e-g, significant hydrology, salt, and $\mathrm{SO}_{4}{ }^{2-}$ effects in Table 4). Drought treatments had $20 \%$ lower DOC concentrations than flooded treatments in all water chemistry treatments (drought mean \pm standard error $=39.9 \pm 3.03 \mathrm{mg} / \mathrm{L}$, flooded $=49.8 \pm$ $3.16 \mathrm{mg} / \mathrm{L}$, Fig. 6). Increased $\mathrm{SO}_{4}{ }^{2-}$, regardless of drought or salinity, led to a $27 \%$ decline in DOC concentrations (mean $=38.2 \pm 1.6 \mathrm{mg} / \mathrm{L}$ ) compared to treatments without $\mathrm{SO}_{4}{ }^{2-}(53.1 \pm 1.93 \mathrm{mg} / \mathrm{L})$. Increased salinity, regardless of the presence of drought or $\mathrm{SO}_{4}{ }^{2-}$, led to a $29 \%$ decline in DOC concentrations (mean $37.7 \pm 1.42$ for ASW and ASW-SO ${ }_{4}$ ) compared to treatments without the addition of salts (mean $=53.5 \pm 4.18 \mathrm{mg} / \mathrm{L}$ for DI control and $\mathrm{SO}_{4}$ only treatments). Drought and salinity combined led to a $49 \%$ decline in DOC (34.8 \pm $3.14 \mathrm{mg} / \mathrm{L})$ compared to the flooded control (mean $=69.3 \pm 2.2 \mathrm{mg} / \mathrm{L}$ ). Chloride concentrations were negatively correlated with the average DOC:DON ratio in the salinity treatments (Fig. 6h).

\section{Discussion}

In field observations in a mature forested wetland (Inflow) and a restored wetland (Midpoint and Outflow) we found that the combination of drought and increased salinity reduced DOC concentrations by $\sim 50 \%$ in surface water. The microcosm experiment showed a similar decline in DOC in response to drought and salinity (49\% decline). These declines in DOC concentrations reduced annual export of DOC from this coastal forested wetland to the estuary by $\sim 70 \%$ and dampened storm fluxes of DOC by up to $76 \%$. It is particularly remarkable that these dramatic changes in the magnitude and timing of DOC exports from a coastal wetland resulted from only a modest increase in salinity (peak salinities in our study were $<6 \mathrm{ppt}$ ) and are happening ahead of major changes in plant community structure (Hopfensperger et al. 2014). Our results show that both drought and increased salinization, due to direct human activities or sea-level rise, can substantially alter the carbon exchange between coastal forested wetlands and estuaries.

\section{Controls on DOC concentrations}

Salinity was an important driver of DOC concentrations in all three sites and in the microcosm experiment. The exact mechanism by which drought and salinity caused the declines in DOC concentration is not clear at this point. In the field, decreased plant productivity, salt-generated flocculation, and increased mineralization during periods of droughtinduced salinization could all act in concert to cause the large decreases in DOC observed in all three sites. We have measured a $50 \%$ decline in growth of the dominant tree in flooded areas that have experienced increased salinity (Powell et al. 2016). The other drivers of DOC concentration in addition to salinity, temperature and nutrients, also suggest that part of the decline of DOC concentrations is due to changes in terrestrial and aquatic plant productivity. The positive 
relationship between DOC and temperature is likely caused by higher aquatic plant productivity during warmer months of the year. A similar study in a forested wetland in South Carolina also found temperature to be an important driver of DOC concentrations in surface water (Chow et al. 2013). Nitrate concentrations were negatively correlated to DOC in all three sites. While it is possible that higher nitrate concentrations could increase microbial activity and consumption of DOC (Lutz et al. 2012), the negative trend observed here is more likely related to the timing of fertilizer addition in the upstream farm. The highest nitrate concentrations at the site usually occur in the early spring after fertilizer application before planting (Ardón et al. 2010). These high $\mathrm{NO}_{3}-\mathrm{N}$ periods are also periods of low DOC due to low temperatures and low plant activity. On the other hand, phosphorus concentrations (SRP) were positively related to DOC concentration. Higher nutrient concentrations likely increase aquatic plant productivity that can increase DOC production, provided the timing of nutrient delivery corresponds to the period of elevated plant productivity. Overall, our results suggest that salinity may alter DOC export through changes in plant productivity before major changes in plant community composition occur (Hopfensperger et al. 2014).

Because we did not include plants in the soil columns in the microcosm experiment, declines in DOC in that experiment were due to reasons other than changes in plant productivity. In the microcosm experiment the combined effects of drought $(20 \%$ decline) and salinity (29\% decline) were additive (49\% decline in drought and salinity combined). Sulfate also led to a similar decline in DOC concentrations (27\% decline), which could be due to increased mineralization, as has been seen in previous studies (Weston et al. 2011). However, we did not measure an increase in $\mathrm{CO}_{2}$ fluxes related to increased sulfate (Ardón, data not shown). It is clear from our results that both salinity and sulfate are important drivers of DOC concentrations, and it is important to understand their separate and combined effects.

Even though we saw clear evidence of decreased DOC concentrations with increasing salinity in both the field and the microcosm experiment, the fate of that carbon is not clear. Some of it might be exported as particulate organic carbon (POC) after flocculation. We have not measured POC export from the TOWeR site. However, given the slow water velocity, POC export occurs mainly during storms or wind tides, suggesting that increased salinity could make carbon export to estuaries more episodic. The POC could return into solution if diluted by freshwater, but preliminary laboratory assays suggest that this salinity induced flocculation is not easily reversible (Ardón, unpublished data). Another alternative is that the carbon enters soils and is rapidly broken down by microbes taking advantage of increased $\mathrm{SO}_{4}{ }^{2-}$. Increased $\mathrm{C}$ mineralization and faster soil $\mathrm{C}$ loss has been observed in various field and laboratory experimental salt additions (Weston et al. 2006; Chambers et al. 2011; Weston et al. 2011). However, we have not seen evidence of increased $\mathrm{C}$ mineralization with increasing salinity, indeed $\mathrm{CO}_{2}$ fluxes decreased with salinity treatment in the microcosm experiment (Ardón, data not shown). It is also possible that the $\mathrm{C}$ flocculates could be deposited in soil for long-term $\mathrm{C}$ storage. Flocculation has been shown to lead to $\mathrm{C}$ sequestration in lakes (von Wachenfeldt and Tranvik 2008). The ultimate fate of that $C$ will depend on both the quality of the POC (Osburn et al. 2011), and on how the microbial community adapts to increased salinity regimes.

Laboratory flocculation assays suggest that up to $13 \%$ of DOC in surface water can be immediately transformed to POC upon exposure to artificial seawater (Fig. 5). This rate of flocculation is slightly higher than has been previously reported (Mulholland 1981; Sholkovitz 1976), and these higher rates of POC formation may be due to the higher initial DOC concentrations in our samples $(\sim 40-60 \mathrm{mg} / \mathrm{L})$ compared to previous studies (4-20 mg/L, Mulholland 1981; Sholkovitz 1976). Declines in sea-salt deposition to coastal regions have been proposed as one mechanism driving large-scale increases in DOC fluxes from terrestrial forests and grasslands (Monteith et al. 2007). Our study supports this hypothesis, clearly demonstrating that the direct supply of marine salts to coastal freshwater wetlands dramatically reduces their DOC concentrations and export.

We found that both DOC quantity and quality $(\mathrm{C}: \mathrm{N}$ ratio) were affected by salinization. The ratio of $\mathrm{C}: \mathrm{N}$ (DOC:DON) that we measured in the field was similar to that reported in a forested wetland in South Carolina (Chow et al. 2013). The decline in the C:N ratio of dissolved organic matter during salinization events or exposure suggests that salinity has a larger effect on the solubility, flocculation or biological assimilation 
of low $\mathrm{N}$ content organic molecules, leaving the relatively $\mathrm{N}$ rich molecules behind. This agrees with previous studies that have shown that salinity can lead to the loss of carbon rich humic components (Sholkovitz 1976). Thus increased salinity could increase the quality of the remaining dissolved organic matter, since higher $\mathrm{N}$ content is typically related to higher bioavailability (Lutz et al. 2011). This hypothesis requires further exploration as the $\mathrm{C}: \mathrm{N}$ ratio is only one of many factors which determine bioavailability of dissolved organic matter (Bianchi 2011).

\section{Hydrologic control of DOC export}

Remarkably, the range in annual DOC export observed from the TOWeR site over just 5 years spans the full range of DOC export reported for 191 wetlands worldwide $\left(50-220 \mathrm{~kg} \mathrm{ha}^{-1}\right.$ year $^{1}$, (Mulholland 2003). As expected export of DOC from the TOWeR site is linked to water export (Tables 2, 3). The amount of DOC export from the TOWeR site was lowest in years with the lowest flow (2008-2009 and 2011-2012, Table 3). In 2008 and 2009 flow was low due to a severe drought in the region (Palmer drought index value-1.92, State Climate Office of NC). In 2011-2012 water flow out of the site was low even though it was not a drought year. Despite overall increases in flooding and water elevation since restoration (Ardón et al. 2010), water flow out of the site was lowest the last year of the study (Table 3). At this point it is not clear why flow from the site was low that year, but we believe that a decrease in the difference in water elevation between the site and the downstream canal (i.e. a decline in head) after removal of a pump station is partially responsible for the decline. Others have also reported decreases in DOC and DON export related to decreases in flow (Eimers et al. 2008). A recent meta-analysis found that variation in DOC export from 550 catchments worldwide was related to discharge (Alvarez-Cobelas et al. 2012). Given that climate change models predict increased frequency and duration of droughts and increased intensity of storms, our results suggest that export of
DOC to coastal areas is likely to become more episodic. Furthermore, the decreased storm export during high salinity periods we measured suggests that saltwater incursion will make those episodic $\mathrm{C}$ pulses smaller, further decreasing $\mathrm{C}$ export to estuaries.

\section{Conclusions}

Saltwater incursion into coastal freshwaters is likely to occur more regularly, over larger areas, and for longer durations in the future. Reductions in freshwater discharge as a result of more intense and extended droughts, together with sea-level rise will make this trend inevitable. Human management of water infrastructure throughout the coastal landscape may exacerbate this trend through water withdrawals and soil oxidation, or may impede it through water control structures and active drainage. In support of our initial hypotheses, results from this study suggest that drought and low level, seasonal salinization of coastal wetlands are already substantially altering the magnitude and timing of wetland derived carbon reaching downstream coastal ecosystems. Well in advance of significant sea-level rise, saltwater incursion is reducing the flux of energy between the continent and the coast.

Acknowledgments We thank M. Burke-Scoll, K. Ballance, and A. Fedders for help in the field and the lab. We thank D. Kong for working on the data for Fig. 5. We thank Drs. Mark Brush, Scott Neubauer and one anonymous reviewer for helpful comments that improved the manuscript. This research was supported by GDSMB private gift in support of basic research, a grant to E.S. Bernhardt from the U.S. Department of Energy's Office of Science (BER) through the Coastal Center of the National Institute for Climatic Change Research at Tulane University, and NSF DEB-1021149. M. Ardón was supported by NSF DBI-0805576, DBI-1216512, DEB-1452886, and EF1426892 .

\section{Appendix}

Table 5 and Fig. 7. 
Table 5 Candidate multiple regression models for DOC and $\mathrm{C}: \mathrm{N}$ ratio at the Inflow, Midpoint, and Outflow for each possible number of model coefficiens (k), including intercept
$\mathrm{Q}=$ discharge. Reported statistics include adjusted $r^{2}$ $\left(\mathrm{r}_{\text {adj }}^{2}\right)$, Akaike's Information Criterion (AIC), the difference between the candidate and the best model AIC $\left(\Delta_{\mathrm{i}}\right)$, and the residual sum of squares (RSS). Candidate models with lowest AIC are in bold and coefficients are reported in Table 2

\begin{tabular}{|c|c|c|c|c|c|c|}
\hline Model & $\mathrm{K}$ & $\mathrm{r}_{\mathrm{adj}}^{2}$ & $\mathrm{Cp}$ & AIC & $\Delta_{\mathrm{i}}$ & RSS \\
\hline \multicolumn{7}{|l|}{ Inflow $D O C$} \\
\hline $\mathrm{Cl}^{-}$ & 2 & 0.23 & 54.54 & 1079.2 & 46.5 & 49532.5 \\
\hline $\mathrm{Cl}^{-}$, Temp & 3 & 0.31 & 29.47 & 1049.6 & 16.1 & 42093.8 \\
\hline $\mathrm{Cl}^{-}$, Temp, $\mathrm{pH}$ & 4 & 0.37 & 8.91 & 1037.0 & 3.4 & 39032.7 \\
\hline $\mathrm{Cl}^{-}$, Temp, $\mathrm{pH}, \mathrm{NO}_{3}{ }^{-}$ & 5 & 0.38 & 7.12 & 1035.5 & 1.92 & 38171.0 \\
\hline $\mathrm{Cl}^{-}$, Temp, pH, $\mathrm{NO}_{3}^{-}, \mathrm{SRP}$ & 6 & 0.40 & 5.60 & 1033.6 & 0.00 & 37567.1 \\
\hline $\mathrm{Cl}^{-}$, Temp, $\mathrm{pH}, \mathrm{NO}_{3}{ }^{-}, \mathrm{SRP}, \mathrm{Q}$ & 7 & 0.40 & 7.00 & 1034.9 & 1.37 & 37445.3 \\
\hline$C: N$ ratio & 2 & 0.29 & -1.39 & -731.0 & $\mathbf{0}$ & 4.28 \\
\hline \multicolumn{7}{|l|}{$\mathrm{Cl}^{-}$} \\
\hline $\mathrm{Cl}^{-}, \mathrm{NO}_{3}^{-}$ & 3 & 0.29 & -0.19 & -729.8 & 1.18 & 4.26 \\
\hline $\mathrm{Cl}^{-}, \mathrm{NO}_{3}^{-}, \mathrm{Q}$ & 4 & 0.29 & 1.51 & -728.1 & 2.87 & 4.25 \\
\hline $\mathrm{Cl}^{-}, \mathrm{NO}_{3}^{-}, \mathrm{Q}, \mathrm{SRP}$ & 5 & 0.29 & 3.22 & -726.3 & 4.70 & 4.24 \\
\hline $\mathrm{Cl}^{-}, \mathrm{NO}_{3}^{-}, \mathrm{Q}, \mathrm{SRP}, \mathrm{Temp}$ & 6 & 0.29 & 5 & -724.7 & 6.35 & 4.24 \\
\hline $\begin{array}{l}\mathrm{Cl}^{-}, \mathrm{NO}_{3}{ }^{-}, \mathrm{Q}, \mathrm{SRP}, \mathrm{Temp}, \mathrm{pH} \\
\text { Midpoint DOC }\end{array}$ & 7 & 0.28 & 7 & -722.7 & 8.34 & 4.24 \\
\hline $\mathrm{Cl}^{-}$ & 2 & 0.38 & 87.7 & 1049.8 & 183.5 & 28586.2 \\
\hline $\mathrm{Cl}^{-}, \mathrm{SRP}$ & 3 & 0.49 & 21.2 & 1008.4 & 142.1 & 21275.0 \\
\hline $\mathrm{Cl}^{-}, \mathrm{SRP}, \mathrm{NO}_{3}^{-}$ & 4 & 0.52 & 9.4 & 998.3 & 132.1 & 19801.6 \\
\hline $\mathrm{Cl}^{-}, \mathrm{SRP}, \mathrm{NO}_{3}^{-}, \mathrm{Q}$ & 5 & 0.54 & 5.15 & 945.4 & 79.2 & 19127.7 \\
\hline $\mathrm{Cl}^{-}, \mathrm{SRP}, \mathrm{NO}_{3}^{-}, \mathrm{Q}, \mathrm{Temp}$ & 6 & 0.59 & 5.10 & 872.7 & 6.50 & 18909.2 \\
\hline $\begin{array}{l}\mathrm{Cl}^{-}, \mathrm{SRP}, \mathrm{NO}_{3}^{-}, \mathrm{Q}, \mathrm{Temp}, \mathrm{pH} \\
C: N\end{array}$ & 7 & 0.59 & 7.00 & 866.2 & 0 & 18897.8 \\
\hline $\mathrm{Cl}^{-}$ & 2 & 0.28 & 28.22 & 827.44 & 96.65 & 9673.68 \\
\hline $\mathrm{Cl}^{-}, \mathrm{SRP}$ & 3 & 0.36 & 5.20 & 811.03 & 80.24 & 8548.97 \\
\hline $\mathrm{Cl}^{-}, \mathrm{SRP}, \mathrm{Temp}$ & 4 & 0.38 & 2.98 & 736.07 & 5.28 & 8359.30 \\
\hline $\mathrm{Cl}^{-}, \mathrm{SRP}, \mathrm{Temp}, \mathrm{pH}$ & 5 & 0.37 & 4.03 & 730.79 & 0 & 8316.96 \\
\hline $\mathrm{Cl}^{-}, \mathrm{SRP}, \mathrm{Temp}, \mathrm{pH}, \mathrm{NO}_{3}{ }^{-}$ & 6 & 0.37 & 6 & 732.75 & 1.96 & 8315.19 \\
\hline \multicolumn{7}{|l|}{ Outflow DOC } \\
\hline $\mathrm{Cl}^{-}$ & 2 & 0.38 & 116.4 & 925.6 & 85.6 & 24788.4 \\
\hline $\mathrm{Cl}^{-}, \mathrm{SRP}$ & 3 & 0.54 & 39.4 & 870.2 & 30.2 & 18293.7 \\
\hline $\mathrm{Cl}^{-}, \mathrm{SRP}, \mathrm{Temp}$ & 4 & 0.59 & 14.4 & 847.7 & 7.7 & 16069.5 \\
\hline $\mathrm{Cl}^{-}, \mathrm{SRP}, \mathrm{Temp}, \mathrm{Q}$ & 5 & 0.60 & 10.5 & 843.8 & 3.8 & 15582.6 \\
\hline $\mathrm{Cl}^{-}, \mathrm{SRP}, \mathrm{Temp}, \mathrm{Q}, \mathrm{NO}_{3}^{-}$ & 6 & 0.61 & 6.6 & 840.0 & $\mathbf{0}$ & 15104.8 \\
\hline $\begin{array}{l}\mathrm{Cl}^{-}, \mathrm{SRP}, \mathrm{Temp}, \mathrm{Q}, \mathrm{NO}_{3}{ }^{-}, \mathrm{pH} \\
C: N\end{array}$ & 7 & 0.61 & 7.0 & 840.2 & 0.2 & 14965.5 \\
\hline $\mathrm{Cl}^{-}$ & 2 & 0.08 & 14.5 & -658.2 & 14.9 & 5.55 \\
\hline $\mathrm{Cl}^{-}, \mathbf{p H}$ & 3 & 0.16 & -0.3 & -672.8 & $\mathbf{0}$ & 5.08 \\
\hline $\mathrm{Cl}^{-}, \mathrm{pH}, \mathrm{SRP}$ & 4 & 0.15 & 1.3 & -671.2 & 1.6 & 5.07 \\
\hline $\mathrm{Cl}^{-}, \mathrm{pH}, \mathrm{SRP}, \mathrm{Q}$ & 5 & 0.15 & 3.1 & -669.5 & 3.4 & 5.06 \\
\hline $\mathrm{Cl}^{-}, \mathrm{pH}, \mathrm{SRP}, \mathrm{Temp}$ & 6 & 0.14 & 5.0 & -667.5 & 5.3 & 5.06 \\
\hline $\mathrm{Cl}^{-}, \mathrm{pH}, \mathrm{SRP}, \mathrm{Temp}, \mathrm{NO}_{3}{ }^{-}$ & 7 & 0.14 & 7.0 & -665.6 & 7.2 & 5.06 \\
\hline
\end{tabular}



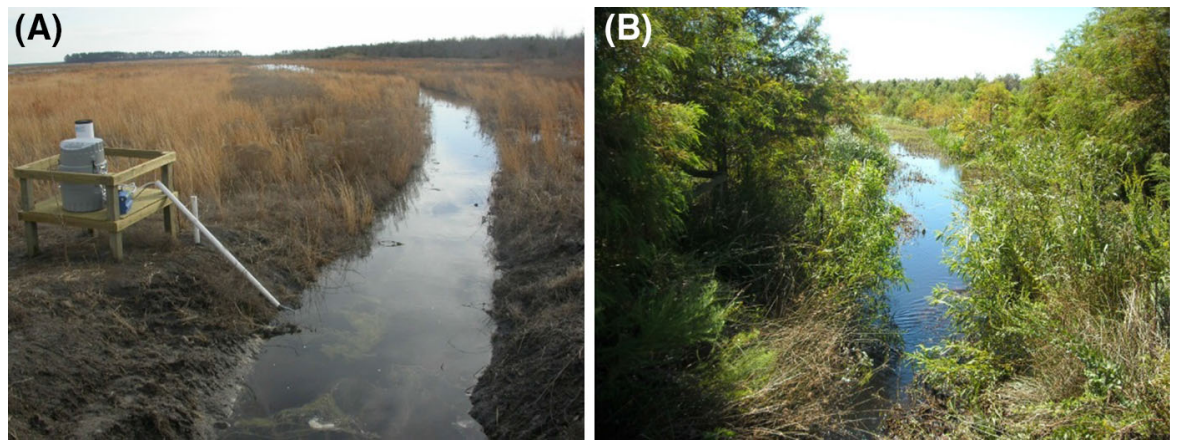

Fig. 7 Photos of the Midpoint site in TOWeR in 2007 (a) and 2012 (b)

\section{References}

Alvarez-Cobelas M, Angeler DG, Sánchez-Carrillo S, Almendros G (2012) A worldwide view of organic carbon export from catchments. Biogeochemistry 107:275-293. doi:10. 1007/s10533-010-9553-z

Anderson CJ, Lockaby BG (2012) Seasonal patterns of river connectivity and saltwater intrusion in tidal freshwater forested wetlands. River Res Appl 28:814-826. doi:10. 1002/rra

Ardón M, Morse JL, Doyle MW, Bernhardt ES (2010) The water quality consequences of restoring wetland hydrology to a large agricultural watershed in the southeastern coastal plain. Ecosystems 13:1060-1078. doi:10.1007/s10021010-9374-X

Ardón M, Morse JL, Colman BP, Bernhardt ES (2013) Droughtinduced saltwater incursion leads to increased wetland nitrogen export. Glob Chang Biol 19:2976-2985. doi:10. $1111 / \mathrm{gcb} .12287$

Battin TJ, Kaplan LA, Findlay S et al (2008) Biophysical controls on organic carbon fluxes in fluvial networks. Nat Geosci 1:95-100. doi:10.1038/ngeo101

Battin TJ, Luyssaert S, Kaplan LA et al (2009) The boundless carbon cycle. Nat Geosci 2:598-600. doi:10.1038/ngeo618

Bauer JE, Cai W-J, Raymond PA et al (2013) The changing carbon cycle of the coastal ocean. Nature 504:61-70. doi:10.1038/nature 12857

Bianchi TS (2011) The role of terrestrially derived organic carbon in the coastal ocean: a changing paradigm and the priming effect. Proc Natl Acad Sci 108:19473-19481. doi:10.1073/pnas.1017982108

Brinson MM, Christian RR, Blum LK (1995) Multiple states in the sea-level induced transition from terrestrial forest to estuary. Estuaries 18:648-659

Carter LM, Jones JW, Berry L et al (2014) chap 17. Southeast and the Caribbean. In: Melillo JM, Richmond Terese (TC), Yohe GW (eds) Climate change impacts in the United States: the third national climate assessment, U.S. Global Change Research Program, pp 396-417. doi:10.7930/ J0NP22CB

Chambers LG, Reddy KR, Osborne TZ (2011) Short-term response of carbon cycling to salinity pulses in a freshwater wetland. Soil Sci Soc Am J 75:2000-2007
Chambers LG, Davis SE, Troxler T et al (2014) Biogeochemical effects of simulated sea level rise on carbon loss in an Everglades mangrove peat soil. Hydrobiologia 726:195-211. doi:10.1007/s10750-013-1764-6

Chow AT, Dai J, Conner WH et al (2013) Dissolved organic matter and nutrient dynamics of a coastal freshwater forested wetland in Winyah Bay, South Carolina. Biogeochemistry 112:571-587. doi:10.1007/s10533-012-9750-Z

Clark JM, Chapman PJ, Adamson JK, Lane SN (2005) Influence of drought-induced acidification on the mobility of dissolved organic carbon in peat soils. Glob Chang Biol 11:791-809. doi:10.1111/j.1365-2486.2005.00937.x

Clark JM, Chapman PJ, Heathwaite AL, Adamson JK (2006) Suppression of dissolved organic carbon by sulfate induced acidification during simulated droughts. Environ Sci Technol 40:1776-1783. doi:10.1021/es051488c

Corbett DR, Vance D, Letrick E et al (2007) Decadal-scale sediment dynamics and environmental change in the Albemarle Estuarine System, North Carolina. Estuar Coast Shelf Sci 71:729-771

Day RH, Williams TM, Swarzenski CM (2007) Hydrology of tidal freshwater forested wetlands of the Southeastern United States. In: Conner WH, Doyle TW, Krauss KW (eds) Ecology of tidal freshwater forested wetlands of the Southeastern United States. Springer, Dordrecht, pp 29-64

Eimers MC, Watmough SA, Buttle JM, Dillon PJ (2008) Examination of the potential relationship between droughts, sulphate and dissolved organic carbon at a wetland-draining stream. Glob Chang Biol 14:938-948. doi:10.1111/j.1365-2486.2007.01530.x

Fenner N, Freeman C (2011) Drought-induced carbon loss in peatlands. Nat Geosci 4:895-900. doi:10.1038/ngeo1323

Hedges JI, Keil RG, Benner R (1997) What happens to terrestrial organic matter in the ocean? Org Geochem 27:195-212. doi:10.1016/s0146-6380(97)00066-1

Henman J, Poulter B (2008) Inundation of freshwater peatlands by sea level rise: uncertainty and potential carbon cycle feedbacks. J Geophys Res Biogeosciences 113:1-11. doi:10.1029/2006JG000395

Herbert ER, Boon P, Burgin AJ et al (2015) A global perspective on wetland salinization: Ecological consequences of a growing threat to freshwater wetlands. Ecosphere 6(10):206. doi:10.1890/ES14-00534.1 
Hopfensperger KN, Burgin AJ, Schoepfer VA, Helton AM (2014) Impacts of saltwater incursion on plant communities, anaerobic microbial metabolism, and resulting relationships in a restored freshwater wetlands. Ecosystems 17:792-807

Kester DR, Duedall IW, Connors DN, Pytkowicz RM (1967) Preparation of artificial saltwater. Limnol Oceanogr 12:176-179

Krauss KW, Duberstein JA, Doyle TW et al (2009) Site condition, structure, and growth of Baldcypress along tidal/ non-tidal salinity gradients. Wetlands 29:505-519

Likens GE, Bormann FH (1995) Biogeochemistry of a forested ecosystem. Springer, New York

Lutz BD, Bernhardt ES, Roberts BJ, Mulholland PJ (2011) Examining the coupling of carbon and nitrogen cycles in Appalachian streams: the role of dissolved organic nitrogen. Ecology 92:720-732. doi:10.1890/10-0899.1

Lutz BD, Bernhardt ES, Roberts BJ et al (2012) Distinguishing dynamics of dissolved organic matter components in a forested stream using kinetic enrichments. Limnol Oceanogr 57:76-89. doi:10.4319/lo.2012.57.1.0076

Mehring AS, Lowrance RR, Helton AM et al (2013) Interannual drought length governs dissolved organic carbon dynamics in blackwater rivers of the western upper Suwannee River basin. J Geophys Res 118:1636-1645. doi:10.1002/ 2013JG002415

Minor EC, Pothen J, Dalzell BJ et al (2006) Effects of salinity changes on the photodegradation and ultraviolet--visible absorbance of terrestrial dissolved organic matter. Limnol Oceanogr 51:2181-2186. doi:10.4319/lo.2006.51.5.2181

Monteith DT, Stoddard JL, Evans CD et al (2007) Dissolved organic carbon trends resulting from changes in atmospheric deposition chemistry. Nature 450:537-539. doi:10. 1038/nature06316

Mulholland PJ (1981) Formation of particulate organic carbon in water from a southeastern swamp-stream. Limnol Oceanogr 26:790-795

Mulholland PJ (2003) Large-scale patterns in dissolved organic carbon concentration, flux, and sources. In: Findlay SEG, Sinsabaugh RL (eds) Aquatic ecosystems: Interactivity of dissolved organic matter. Academic Press, San Diego, pp 139-160

Neubauer SC (2013) Ecosystem responses of a tidal freshwater marsh experiencing saltwater intrusion and altered hydrology. Estuaries Coasts 36:491-507. doi:10.1007/ s12237-011-9455-x
Nixon S (1980) Between coastal marshes and coastal wa-ters: a review of 20 years of speculation and research on the role of salt marshes in estuarine productivity and water chemistry. Estuarine and Wetland processes. pp 437-525

Osburn CL, Handsel LT, Mikan MP et al (2011) Fluorescence tracking of dissolved and particulate organic matter quality in a River-Dominated Estuary. Environ Sci Technol 46:8628-8636. doi:10.1021/es3007723

Powell A, Jackson L, Ardón M (2016) Disentangling the effects of drought, salinity, and sulfate on the growth of baldcypress trees. Restor Ecol (in press)

Raymond PA, Saiers JE (2010) Event controlled DOC export from forested watersheds. Biogeochemistry 100:197-209

Shih JS, Alexander RB, Smith RA et al (2010) An initial SPARROW model of land use and in-stream controls on total organic carbon in streams of the conterminous United States. U.S. Geological Survey

Sholkovitz ER (1976) Flocculation of dissolved organic and inorganic matter during mixing of river water and seawater. Geochim Cosmochim Acta 40:831-845

Teal JM (1962) Energy flow in the salt marsh ecosystem of Goergia. Ecology 43:614-624

Thurman E (1985) Organic geochemistry of natural waters. Kluwer Academic Group, Dordrecht

Tzortziou M, Neale PJ, Osburn CL et al (2008) Tidal marshes as a source of optically and chemically distinctive colored dissolved organic matter in the Chesapeake Bay. Limnol Oceanogr 53:148-159. doi:10.4319/lo.2008.53.1.0148

Tzortziou M, Neale PJ, Megonigal JP et al (2011) Spatial gradients in dissolved carbon due to tidal marsh outwelling into a Chesapeake Bay estuary. Mar Ecol Prog Ser 426:41-56. doi:10.3354/meps09017

Von Wachenfeldt E, Tranvik LJ (2008) Sedimentation in boreal lakes-The role of flocculation of allochthonous dissolved organic matter in the water column. Ecosystems 11:803-814. doi:10.1007/s10021-008-9162-z

Weston NB, Dixon RE, Joye SB (2006) Ramifications of increased salinity in tidal freshwater sediments: geochemistry and microbial pathways of organic matter mineralization. J Geophys Res 111:G01009. doi:10.1029/ 2005jg000071

Weston NB, Vile MA, Neubauer SC, Velinsky DJ (2011) Accelerated microbial organic matter mineralization following salt-water intrusion into tidal freshwater marsh soils. Biogeochemistry 102:135-151. doi:10.1007/s10533010-9427-4 